\title{
The Spectre of History and Constitutional Recognition of Indigenous Australians.
}

\author{
Sathyabhama Daly
}

\author{
James Cook University
}

\begin{abstract}
$\mathrm{T}$ he Speccie Thawley Essay Prize had me thinking about a person or event that helped shape modern Australia. Much has been said about Gough Whitlam and his influence on Australian history. In the contemporary period North Queenslander Noel Pearson, an Indigenous leader, educator and activist has dominated debates in Australian society about Indigenous Rights, education and recognition. I wondered, however, if individuals alone can influence and shape a society, or whether it is the collective consciousness of the people of a country that impacts upon history. This essay therefore is a questioning of modern Australia's perception as an egalitarian society, with its ethos of 'A Fair Go for All', and if it extends to Indigenous and Torres Strait Islanders, the original inhabitants of Terra Australis? My thoughts have been provoked by the failure of successive governments to address the recognition of Indigenous and Torres Islander people in the Australian Constitution.
\end{abstract}

I believe that it is important to recognise Indigenous Australians in the constitution in order to affirm their rights and identity as the original inhabitants of the land. Only by doing so can Australia rewrite Indigenous Australians into their own history and their land. Furthermore, recognition would amend the constitutional error of terra nullius, an error that led to dispossession, marginalisation, and treatment of the original inhabitants of Australia as secondclass citizens until the 1967 referendum. The recognition of Indigenous Australians and Torres Strait Islander populations would address the silences and gaps that continue to haunt the Australian psyche and the unexpressed guilt of a historical wrong done to a nation's people. I came to Australia as a migrant in 1978, and have seen a lot of changes in Australian society, changes of a culturally diverse and integrated nature. However, what continues to perplex me is the silences and gaps around Indigenous and Torres Strait Islander status as the original owners of Australia. It is almost as if a penumbra of guilt shrouds the Australian psyche. Historians, writers, artists and politicians continue to debate the history of Australia. John Howard proposed recognizing Indigenous Australians in the constitution in the 1999 Republic Referendum, which was defeated. Succeeding Prime Ministers such as Kevin Rudd, Julia Gillard, and Tony Abbott have made similar calls for constitutional changes to recognise the original owners. Each time, the movement has been derailed or has lost momentum because there is a fear in the Australian psyche that to recognise the original inhabitants may result in diminished rights for the settler and migrant population.

The concept of terra nullius on which Australia was founded is debated and philosophised but there is no resolution on how to right the wrongs of history. I find it difficult to comprehend why these debates persist and why politicians and the Australian public are so sensitive to the discussion about the recognition of Indigenous and Torres Strait Islanders in the constitution. Am I naïve in assuming Australians need to acknowledge that terra nullius was the key factor in the divisive 
politics that sets Indigenous and Torres Strait Islanders apart from the settler population, because only then can past hurts be healed to forge a more inclusive society for all Australians?

Australians have viewed themselves as the lucky country, of a fair go for all peoples. It is a founding myth that has served to forge an Australian identity, but like most myths need to be dissected and truthfully analysed to see how the failure to recognise Indigenous and Torres Strait Islanders as the original inhabitants of the land has continued to create debate and fear that such a recognition would entail loss of rights for the migrant population or monetary or property entitlements for the original people of the land. But does recognition of Indigenous and Torres Strait Islanders as the original inhabitants of the land have to be associated with fear, guilt and legal recriminations? Would recognition not imply that Australians honour them as the original owners, and wish to amend the constitutional error of history? This is not to create guilt or shame among the settler or migrant population who have contributed to the modern Australian nation. All history is the result of migration and there is no period in the evolution of the human race when humankind lived in an Utopian landscape.

Reading Australian history by colonisers and historians presents two conflicting mythologies. The first is of a prehistory of the Dreamtime mythology of the Indigenous people, which is disrupted by the colonizers world of Urizen, as in William Blake's vision of an authoritarian and vengeful God who robs the inhabitants of their innocence and culture and whose greed corrupts and destroys the idyllic paradise. The reality is there never was a pure sacred history and a chaotic postmodern history. The truth is that all nations and peoples have been impacted by history. Narratives and myths are important for the human imagination, and there is much truth in the violence and degradation of colonisation. However, to continue to reflect on the nightmare of history, to nurture anger, hate or conflict can only result in divisions and further conflicts.

Indigenous and Torres Strait Islander people are a peace-loving and sharing people who have not resorted to violence to plead for their rights as the original inhabitants of the land. Since colonisation all they have asked for is to be recognised as the original owners and to be treated with respect for their culture and traditions. The appeal for recognition is often viewed as divisive by the migrant population because it undermines the contributions made by the settler society. But why should this be? Why should Australians continue to think on binary oppositions that granting Indigenous recognition can only result in undermining the constitution and the rights of all Australians? To be stuck in the wrongs of the past will only lead to conflicts and anger. To seriously consider how this history has impacted on the Indigenous and Torres Strait Islander populations is to negotiate an understanding on how to heal the divisions that continue to haunt the Australian imagination.

Some Australians may argue that as a migrant who came to Australia only 37 years ago, I do not have a right to speak for the settler population, those who carved out an 
Australian identity building the infrastructure, laws, and sacrificing their lives in wars of liberation and democracy. I would defend my argument by saying, having lived here for 37 years I have noticed an inherent racism towards Indigenous Australians that lurks beneath the surface coiled like a snake, rearing its ugly head when the veneer of civility is lifted. One such example is the Adam Goodes's saga that dominated the newspaper headlines in May 2015. Adam Goodes is an Indigenous Australian who was nominated Australian of the Year for his contributions towards overcoming racism in Australian society and for his ability to bring Australians together through his success as an Aussie Rules footballer. However, as in most societies, people are quick to judge and turn against a hero figure if they believe the hero is flawed. Goodes's reaction against name-calling and booing by Aussie rules fans have been seen by many as being overly sensitive and not in the Australian tradition of ignoring taunts.

Gary John's article in The Spectator Australia, "Goodes is a victim, but not of racism" argues "Adam Goodes is a victim of the Aboriginal grievance industry. It started to go wrong for Goodes when he was used as a poster boy by the Recognition movement. That movement is determined to paint this nation as racist in a cynical attempt to rewrite the constitution to gain rights for one race, Aborigines. This is racist" (The Spectator Australia, 8 August 2015, p. xi). So it is racist for Indigenous Australians to ask for recognition in their own country. It is not racist that a constitution was enacted to discriminate against a people who until 1967 were second-class citizens?

Others have condemned Goodes for not living up to the ideal that Australians believe in a Fair Go for All. He had been nominated Australian of the Year, and instead of being grateful he complains about the racism directed at him as an Indigenous Australian. There is no racism in Australian society, they proclaim. The taunts, jeers, and allusions to Simian characteristics are dismissed as Goodes's inability to ignore the abuse. It is easy if one belongs to a dominant group or ideology to dismiss the sensitivity of Indigenous Australians whose identity and culture had been impacted upon by the violence of history. Instead of viewing Goodes's War Dance as a celebration of his culture, some Australians saw it as an affront of Australian values and tradition. The impromptu war dance was deemed offensive, because Goodes held an imaginary spear which was perceived as being directed at the crowd. Who is being paranoid? Goodes in his celebration of his Indigenous identity, or those who believe he had hostile intentions? What imaginary fears did Goodes's Indigenous Dance evoke? Why was Goodes not given the same adulation as the All Blacks when they perform the Maori War Dance?

Adam Roy Goodes's war dance saga and the debates about his use of the racism card to create divisions within Australian society have, to some extent, diminished. But at what price, one would have to ask? An Indigenous hero and Australian of the Year forced to leave because the jeers and jibes could no longer be ignored. Is racism inherent in Australian society? I would answer in the affirmative, because those who wish to assert their individuality or cultural identity that is different from 
the dominant culture are viewed as a threat to the social capital of society. They go against the norms of what the dominant group has decided is the Australian tradition based on Anglo-Saxon values. Indigenous Australians asking for respect and recognition of their culture and traditions in the constitution are suspected of wanting to return to a pristine culture before colonisation. The truth lies between the extremes of the conflicting mythologies of a pristine Indigenous culture before colonisation and a settler culture that has suppressed and imposed its identity on an Indigenous population. How do we resolve these two conflicting ideologies and live in an integrated society that respects the rights of all Australians? I would say by acknowledging Indigenous and Torres Strait Islanders in the Australian constitution. Do we need a plebiscite or referendum for recognition? I would suggest that the Commonwealth Parliament should be able to define the meaning of Indigenous recognition within the constitution. Only then will Australia be able to declare that in amending the constitution the Australian people acknowledge and respect the rights of the original inhabitants of the land. 